\title{
Man, History and Poetry. Dominant Tendencies in Lithuanian $21^{\text {st_Century Documentary Films }}$
}

Images vol. XV/no. 24 Poznań 2014 ISSN 1731-450X

In the history of Lithuanian cinema, documentary film has had a dominant role. The poetical form of the documentary has built a picture of Lithuanian history in Soviet times resistant to 'doctoring', as well as having played an exemplary role in creating the image of Lithuania in Europe in the 1990s. At that time documentary films gained more international recognition than other film genres. The most important of the Lithuanian ones were: Earth of the Blind (Neregiu žemé, 1992) by Audrius Stonys - awarded the European Felix in 1993; The Spring (Pavasaris, 1997) by Valdas Navasaitis - awarded the main prizes at the Cinéma du Réel Festival in Paris, at the L'Alternativa Independent Film Festival in Barcelona, and at Oberhausen; as well as in 2006 the film Before Flying Back to the Earth (Prieš parskrendant į žemę, 2006) by Arūnas Matelis - the first film in the history of Lithuanian cinema to be nominated for an Oscar.

Then there is also the emotional image of children suffering from leukaemia and their difficulties in hospital which also received two highly prestigious distinctions: the Silver Wolf award at the Amsterdam Film Festival, and the Grand Prix in Lipsk. Lithuanian documentary film has also found national and international audiences at numerous documentary film festivals in Lithuania. Importantly, the Vilnius Documentary Film Festival organised in Vilnius every year and Vilnius Film Shorts, as well as the Šoble Festival of student productions - derived from the doyen of documentary film, Henrikas Šablevičius - are at the centre of constant interest and have testified to the strengthening of the documentary's position as one of the most popular and fascinating film genres.

The main and fundamental element of the development of international recognition for Lithuanian film documentaries, however, is to a significant degree a consequence of its remaining true to its traditions and the particular environment of its production. To this very day this remains the accepted practice in Lithuanian documentary film, according to which such a film belongs rather to the sphere of the arts than to the media or journalism and the predominant view is that it should be assessed foremost in aesthetic categories. At the turn of the 21st-century, although the documentary film and its observations have become rather varied in terms of the subject matter it undertakes, there dominates in documentaries, however, an attempt to return to the aesthetics of the cinema of the 1960 - fusing in a poetic way in relation 
to the world outside the visual with the documentary. The concept of documentary film proposed by Grierson as a genre serving information purposes and the education of its citizens - a concept that is very vibrant in the Anglo-Saxon tradition - has not found acceptance in Lithuania. Nor has Grierson's formula for organising documentary film, one that holds that the documentary is produced from public funding and is screened for distribution beyond venues such as cinemas.

Lithuanian documentary films since the 1990 s have most often come from private companies and can be viewed only at film Festivals. Today, there are over 40 such film production companies in Lithuania. These so-called laboratories arise usually from the initiatives of young directors who are in this way searching for a means to realise their ideas. The small production companies that collect funding from various sources are reminiscent of amateur enterprises for which funds are gained from a wide range of means: from engaging private funds - to a search for funding from grants. This particular road towards production gives directors greater independence and allows, consequently, for the maintenance of a consistent personal tone, as well as individual style of film expression. In addition, the growth of private film production companies has lent itself to a similar development of documentary film.

In painting a picture of the Lithuanian documentary film at the turn of the 2oth century it is possible to identify several so-called streams. On the one hand, there is still a vibrant favourite of the two previous decades - the artistic, metaphorised documentary that draws a poetic landscape of provincial reality in the countryside. The co-founder of this model was a leading Lithuanian documentary filmmaker, Henrikas Šablevičius, who in his creative output as well as educational activity had an impact on the form of the Lithuanian film documentary and became, at the same time, a master and a paragon for younger apprentices of the film arts. On the other hand, there have also arisen films with a journalistic focus, ones that portray historical events and biographies. One important change is also the subject of the Holocaust, which film has undertaken to portray, together with works that interpret the outside from the perspective of the woman's 'patient eye'.

Towards humanism the Henrikas Šablevičius School
Henrikas Šablevičius is the creator of the poetic documentary, whose ascendance took place at the end of the 1960 . His was an innovative approach towards film at that time, based on relating a story without any commentary off camera with the aid of sophisticated editing, lyrical expressions, synchronised dialogues and the patient observation of man and the outside world. In the history of Lithuanian cinema, the creative work of Šablevičius gained an important place and became a model of poetic humanism and thinking for many generations of filmmakers. His so-called apprentices became known for their documentary films, characterised by their focus on the personal, avoidance of the limelight as a medium, authentic dialogue, marked close-ups and a long and careful observation of immediate reality. During the period of political 
transformation in 1993 it was at the initiative of Henrikas Šablevičius that the Department of Film and Television was established as part of the Lithuanian Academy of Music and Theatre in Vilnius. This is not only the first and only centre of Film Studies in Lithuania, but also a place that creates a creative community with a concern for a high level of artistic film documentary in Lithuania.

The films that represent the creative growth of the Henrikas Šablevičius School are mainly the ones made by his students at the Department founded by the director: Audrius Stonys, Arūnas Matelis, Janina Lapinskaitè, Inesa Kurklietytè, Giedrè Beinoriutė and Vytautas V. Landsbergis. Audrius Stonys, a leading documentary film director, whose films continue to remain bound in the aesthetics of poetic humanism, would comment many years later:

Henrikas Šablevičius instilled in me a love for the landscape of the countryside and the wisdom of people. The works of this director have had an enormous influence on me, and have also shaped my style of film expression. $[\ldots][1]$

Among the directors with the aid of careful and patient observation representing aspects of the culture of the countryside and the poeticised world of the village, one could name all the respective generations of documentary makers. Among those of the older generation, who made their debut in the 1970s and 1980s, are the filmmakers Julia and Rimantas Gruodis, and Diana and Kornelijus Matuzevičius. Their documentaries deal with the specific, particular qualities of the countryside, and are shot in a calm and reflective manner, showing people who despite their difficulties live in accord with nature and the tradition of village culture. In The Swamp (Lieknas, 2010), the Gruodis team relates the story of an 80-year-old woman, who has built a humble house with her own hands, dug out a well and in place of a muddy patch made a beautiful garden. The earlier film The River (Upé, 2009), was awarded the first prize in the Karlove Vary Film Festival in the category of Film Shorts and was also recognised as the best Lithuanian entry film for 2009. This documentary portrays people living by the estuary of rivers, next to a toxic chemical plant; while the work by Diana and Kornelijus Matuzevičius The Horizons or Life at Louvres (Horizontai arba gyvenimas luvruose, 2005) portrays the farmer Vytautas, who is breeding sheep. The peasant, living among the hilly landscape, is convinced that it is, in fact, Lithuania that is the holy Louvers and the most beautiful place to be. Confirmation of this for him are the idyllic landscapes presented at sunrise and the sunset over the hilly countryside of Samogitia.

The work of the older generation of filmmakers also emphasizes the harmonic co-existence of man and nature, where the rhythm of

[1] "Nie robię filmów dla widza siedzącego przed telewizorem $\mathrm{z}$ pilotem w ręku" [I do not make films for those sitting in front of the television, thumb poised on the remote control], "Anna Mikonis talks to Audrius Stonys", Kwartalnik Filmowy 2007, no. 57-58, p. 267. 
nature is entwined firmly with the life of those living there and where work on the land is accompanied by poetic images of the changing seasons (the thawing of snow, sprouting of seeds and the birth of animals and people). The leisurely rhythm of these films is in tune with the natural rhythm of the village life for the people and often draws upon an idyllic landscape of the reality.

The innovative voice of the middle generation of directors that made its debut in the 1990s, in the first independent film studio 'Kinema', also found its expression in documentary film. The works of Audrius Stonys, Vytautas V. Landsbergis, Arūnas Matelis, and Valdas Navasaitis, also slowly began to gain international success. At the end of the 199os, it became apparent, however, that the movement of young directors was but a passing phenomenon.[2]Each began to take an independent path whether in making films or in production. Vytautas V. Landsbergis began to make feature films and sometimes turned to documentaries to portray some historic event, Arūnas Matelis and Valdas Navasaitis at present are film producers, while Audrius Stonys remains faithful to the aesthetic of documentary film.

The documentary output of Audrius Stonys is one of the most interesting in contemporary Lithuanian film. It is based on a registration of simple acts, characterised by a predilection for lyricism in the creation of a narration based on a leisurely tracing of people's fate and actions. It is distinguished by the emotion of its protagonists, silence and the definition of people by means of the monotonous routines they carry out. Stonys's documentaries feature a leisurely pace of events, emotionless expressions of the protagonists, a tendency for extended shots, as well as new dialogues where calm and monotony prevail. These are portrayals of the provincial world, full of grey tones, lonely old people and curious, as well as at times, tragic tales. The film Four Steps by Stonys (Keturi žingsniai, 2008) is a hybrid of an ethnographic document and country folk ballad.

These very steps are, in fact, films relating Lithuanian wedding celebrations. Stonys portrays the ritual of weddings in Lithuania, showing their changes through time from the 1960 s up to this very day. The documentary chronicle is accompanied by a reading from Lithuanian classical literature, the verse by Kristijonas Donelaitis, as well as lyrical peasant songs.

The tragic story of the burning of a wedding couple's home is shown by the film Walked through Fire, You Were With Me (Ašperejjau ugni, tu buvai su manim, 2011), while The Bell (Varpas, 2007) tells the legend of the bell lying for 300 years at the bottom of Lake Plateliai. The landscape of the film, enveloped in the midst of the largest Lithuanian lake, ensconced in the hilly countryside of Samogitia and complemented by a searching, calm observation of the autochthons relating the

[2] See A. Mikonis, "Ferment intelektualny w kinie litewskim" [Intellectual Ferment in Lithuanian Film], Kwartalnik Filmowy 2007, no. 57-58, p. 265. 
legend of the disappearance of the bell, creates a magical, suggestive visual texture to the film.

One of the recent films by Stonys concentrates on the fate of those trapped in loneliness. The moving documentary Ramin (Raminas, 2011) is a Lithuanian-Georgian coproduction with its action set entirely in Georgia. Although the protagonist of the film is a sporting legend, Stonys does not show us the sporting achievements of the Georgian wrestler but, rather, a portrait of a lonely and neglected old man. Raminas Lomsadze lives alone in a small Georgian village. We observe his daily routine. A scene that is highly suggestive, integral to Georgian culture, is the meeting of friends at the Raminas birthday table. Here we witness the woven fabric of a colourful discussion, dance, recollections and songs of a free Georgia. The film shows its protagonist in a loving light and a delicacy that is difficult to put exactly into words. The unhurried rhythm of the film, together with the harmony of sound and scenes (camera, Audrius Kemežys) creates an unusually pure and intensive tone in this documentary.

The intriguing attempts at capturing the daily experience of protagonists who are in their own way unique, provincial and exotic can also be found in the films of young directors. Filmmakers such as Marat Sargsyan, Lina Lužyte, Mindaugas Survila and Linas Mikuta carefully observe the colourful inhabitants in Lithuania and Belarus, taking on a wide variety of models of life and highly surprising forms that exist in Lithuanian and Belarusian families. These young filmmakers choose neglected and provincial terrains in derelict post-Soviet villages, cut off from civilisation, where people live wedded to the world of nature or are vegetating beyond the social pale.

Recognised as the best Lithuanian documentary for 2011 The Field of Magic (Stebuklu laukas, 2011) from Mindaugas Survila is a documentary epic poem about those living on a rubbish tip. The film shows how people beyond the social pale, socially marginalised, exist, the majority earning their living by penetrating the mountains of refuse in search of metal - living in small cardboard shacks. The rhythm of life is marked out by the arrival of

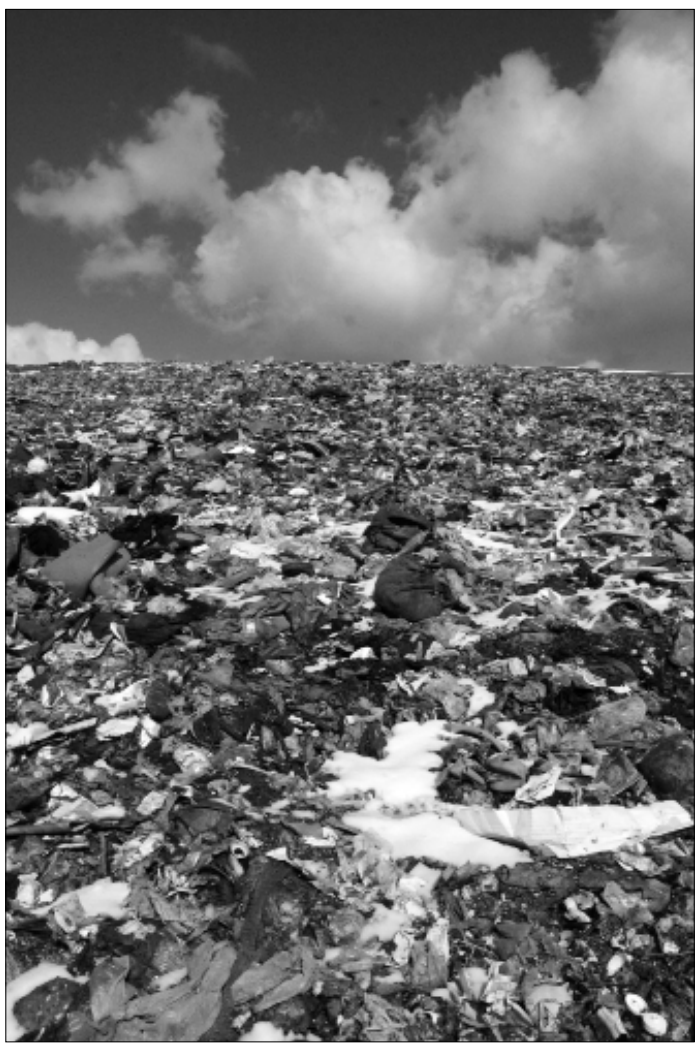
the rubbish truck. The director does not place his film within the stream that Brian Winston named victim documentaries.[3]The documentary
The Field of Magic, dir. Mindaugas Survila, 2011 


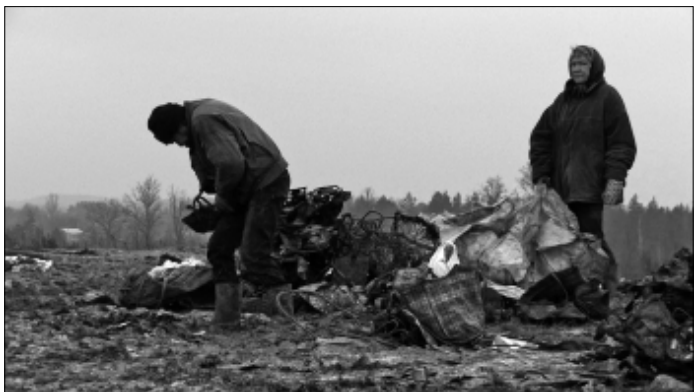

The Field of Magic, dir. Mindaugas Survila, 2011

does not undertake ethical questions, ones concerning the poor and the elimination of these from society. Quite the opposite, within the appalling images of people on a rubbish tip the director sets up an artistic and humanist setting. Survila in fact continues the tradition of Šablevičius in portraying a romantic context by placing emphasis on the visual side of the film and its humanistic message.

The film is set with the image of two deer walking through a romantic winter forest clad in a blanket of snow. Then, after an editorial cut we see a close-up of a colourful Jay in a feeding tray illuminated by the intensive sun. These two rather illustrative images (opening and closing the film) imbue a softening form to the future dramatic and naturalistic story of the people. Among the daily routines of poking about in rubbish, being down and out, hunger and a search for food and water, the director also integrates two moving sequences.

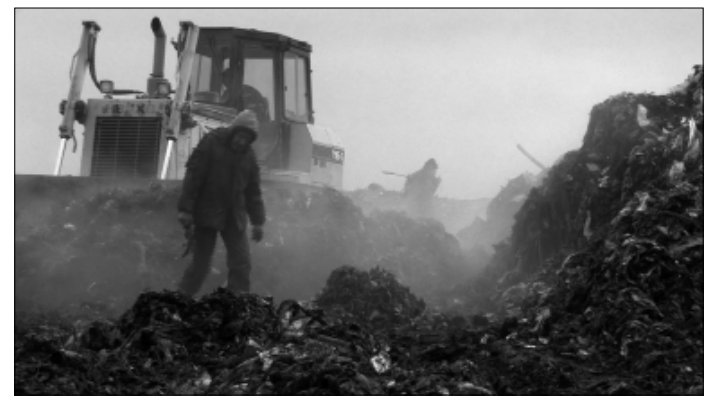

The Field of Magic, dir. Mindaugas Survila, 2011 A mother after a long separation rings to her son, and crying, begs him to come and see her. He does not mention that for the past 20 years he has been living on a rubbish tip. The next sequence shows a Christmas Eve gathering in a small barrack, where the camera slowly portrays people sharing the holy wafer and exchanging wishes. These scenes carve a picture of people with the all too human needs of love and emotion - people who became what they became as a result of various circumstances.

Protagonists that are not part of the mainstream are also portrayed in the films Dzukija's Bull (Dzūkijos Jautis, 2013) by Linas Mikuta, Igruški (Igrushki, 2012) by Lina Lužyte, Sasha (Saša, 2006) by Romas Lileikis, and Father (Tévas, 2012) by the Armenian Marat Sargsyan, a graduate of Film and Television Direction at the Lithuanian Academy of Music and Theatre. Dzukija's Bull is a story

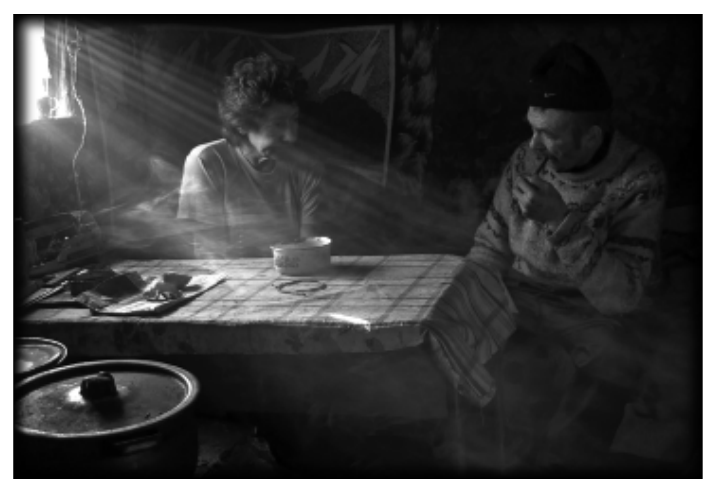

The Field of Magic, dir. Mindaugas Survila, 2011 about an inhabitant of a Dzükija village, who because of his unusual strength is known as Jautis (the bull). The scenes in which the visual dominate present the aesthetic scenery of the village hut, fields and horses but do not depart from the well worn tradition of Lithuanian documentaries. In the film Igruški in turn we see a picture of people in provincial towns in Belarus. The camera patiently follows lonely people who live on the very margins and whose only source of survival is the illegal sale of their soft toys. 
The film by Roman Lileikis $S a s ̌ a$ is a cultural and literary portrayal of the oldest suburb of Vilnius, Užupis, seen through the eyes of Sasha and Laurynas, who have lived here since birth. Father (Tévas, 2012, Silver Horn for the best MFF documentary film in Kraków) is, however, a story of the former 'Godfather of the Soviet mafia' - Vidas Antonovas. This protagonist once stole around 1 million roubles from government institutions and hijacked a government plane. After spending 20 years in jail, he devoted all of his energy to his family. The film therefore tells the story of a 71-year-old man and his routines, one living in the Lithuanian countryside and raising 10 children. The director patiently observes his protagonist's daily routines, does not judge him, providing a uniform setting of silent images that portray the old man in the provinces, who loves his family. The dominating images contained in the films of Audrius Stonys, Marat Sargsyan, Mindaugas Survila, Lina Lužytė, Romas Lileikis, Julia and Rimantas Gruodis, and Diana and Kornelijus Matuzevičius continue not only the poetical documentary characteristic for Lithuanian cinema but, at the same time, build a bridge between the figure of the lost, old man, eccentric and that of the contemporary man, who in the whirlwind of cultural changes does not change and who, against all the difficult circumstances such as poverty and loneliness, tries to preserve his internal harmony.

Among the group of young documentary filmmakers one notable film debut is that of a young academic, and anthropologist of culture, Mantas Kvedaravičius in his work Barzakh (2011). This documentary was made after three years of empirical investigation conducted by the director at the University of Cambridge on the subject of violence and evil in society, and the impact on a person's psyche. The scope of the field investigation by Kvedaravičius covered the northern Caucasus. He shot over 100 hours of material, which produced a one-hour documentary on violence, torture and the sudden disappearance of people in Chechnya. This debut document reveals the story of the small Chechen village where a young man disappeared. The

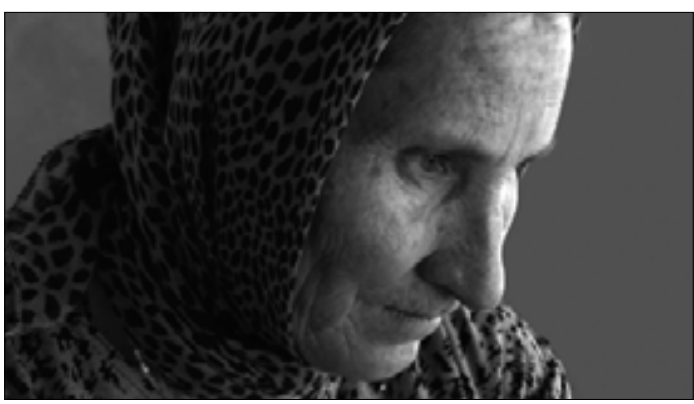

Barzakh, dir. Mantas Kvedaravičius, 2011 impossibility of conducting a proper investigation, the lack of clear answers and numerous conjectures, all serve to strengthen the impression of the absurd - and dissolve into a situation of helpless anticipation.

The film can be placed in the context of the aesthetic of silent and careful observation. Mantas Kvedaravičius does not provide his subject matter as a media form. A woman's nightmare as mother and wife for the past six years, searching for her son and husband, is shown with the aid of carefully chosen film techniques that help to reveal the second, unseen dimension of reality and at the same time serve to emphasise the emotional state of people living in continual fear, without information, in pain, and bound in a sense of entrapment. The 


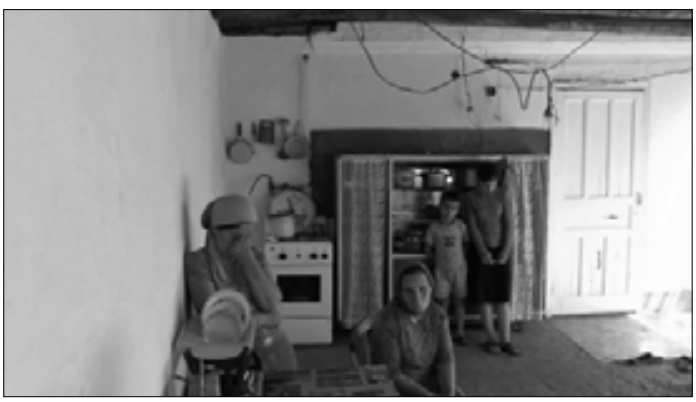

Barzakh, dir. Montas Kvedaravičius, 2011 film therefore has a structure that is close to a dream-like state. The scenes from the life of Hamdans family are interwoven with poetic images of nature, water, air, longshots of faces, prayer and fortune-telling. For the director these are metaphors of a state in which the sense of reality becomes blurred and relaxed. The appalling confines of the jail plastered in blood, where prisoners are tortured, the testimonies of people that have been physically disfigured and tortured, their helplessness, the atmosphere of insecurity and the suspension between the two worlds of the dead and the living, all serve to make this film one that shatters our sense of reality - one that shall long remain in our memory.

The debut of Kvedaravičius is a form of documentary essay that brings a new perspective to the ongoing situation in Chechnya. It brings to light the issue of torture, kidnapping and the instruments of repression used by the authorities that are often not seen, swept to the margins of public discussion - ones that still present a constant grievance for Chechen society. This painful and at the same time important film about human pain, helplessness in the face of rape and violence in the northern Caucasus, has evoked enormous interest. Barzakh opens the 61st Berlin International Film Festival and has received the Amnesty International award, as well as the Eucemenical Award, while at the festival in Belgrade it received the Grand Prix, and the FIPRESCI award during the Black Nights Film Festival in Tallinn. However in Moscow, at the Lithuanian Film Festival, it met with a lack of goodwill from the organisers and was banned and not shown.

This is the first attempt at a change of perspective and function of Lithuanian documentary film, which finally has drawn our attention, and is taking on a voice in important social issues. The incursions into these matters by Mantas Kvedaravičius are worthy indeed and it is hoped that they inspire others who shall follow in his footsteps.

From Lithuania to Siberia and to Israel memory and history
One phenomenon that has been changing the landscape of Lithuanian cinema is films that are devoted to historical facts. The largest impetus of the wave of films looking back into history came in the first half of the 1990s, [4]whereas at the turn of this century the examination of historical themes in Lithuanian documentary films became somewhat less common. From time to time, however, films are made that deal with the most painful events in the annals of Lithuanian history, ones that touch upon the Lithuanian partisan movement, Soviet annexation and collective deportations. The action of these films covers World War II, the post-war period and the Soviet occupation.
[4] See G. Arlickaite, "Litwa: Odrodzenie kina dokumentalnego", [Lithuania: The Revival of Documentary Film], in: Dokument po przełomie. Film dokumentalny lat 9o. w Europie Środkowo-Wschodniej, ed. J. Głowa, Uniwersytet Jagielloński, Kraków 1999, p. 12. 
Documentary films on the latest history testify to the continual need for documenting events that in the times of communism were taboo subjects and destined to be erased from the social memory and to be marginalised. A new theme, however, is that of the Holocaust and the cultural heritage of the Jewish people.

One example of one such artistic project is the film by Giedre Beinoriute Grandpa and Grandma (Gyveno senelis ir bobute, 2007). In this documentary, realised by the private production company 'Monoklis', the filmmaker relates the story of her grandmother, who was deported by train in 1948 with her entire family to Siberia. The innovative form of the film, combining animation with fragments of film chronicles, as well as photographs from her own album and the director's commentary off camera, all build a tragic portrayal of one of the many thousands of families deported deep into Siberia - a film that makes relevant again this particular issue of the painful period of collective Stalinist deportations.

On a different theme, in the film How We Played the Revolution (Kaip mes žaideme revoliucija, 2011) by Giedre Žičkyte, the subject of the independent streak in the 1990s is portrayed in a satirical picture of the history of the Lithuanian cult rock group 'Antis', founded during perestroika. The film portrays the band's colourful history and, at the same time, reminds one of the period of the singing revolution of the 1990s, which helped defeat the Soviet system.

In turn, the film by Rimtautas Šilinis, Lithuania in World War II. Cinematographic Documents (Lietuva antrajame pasauliniame kare. Kino dokumentai, 2006), is a mosaic edited in chronological order of newsreel fragments that portray the events of the Soviet occupation of Lithuania, which finished, as the documents prove, in August 1993 when the Soviet army finally left.

Next, there is a large group of films that devote themselves to the portrait of Lithuanian partisans, such as the tragic fate of the last anti-Communist underground soldier,

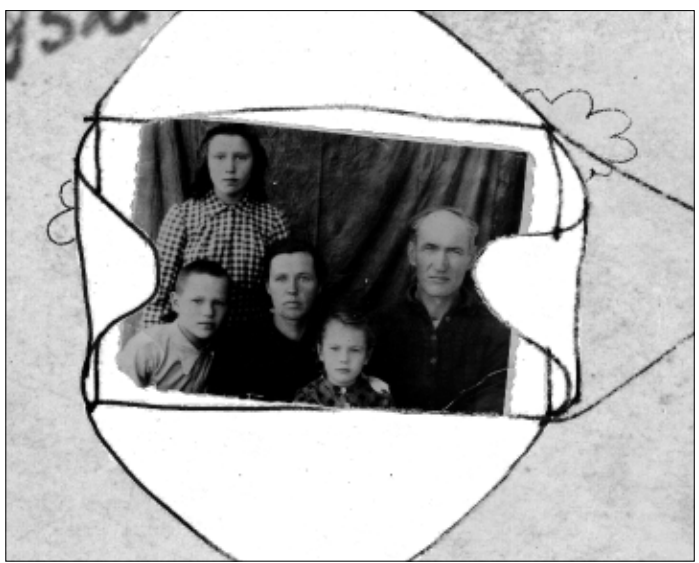

Grandpa and Grandma, dir. Giedrè Beinoriutè, 2007

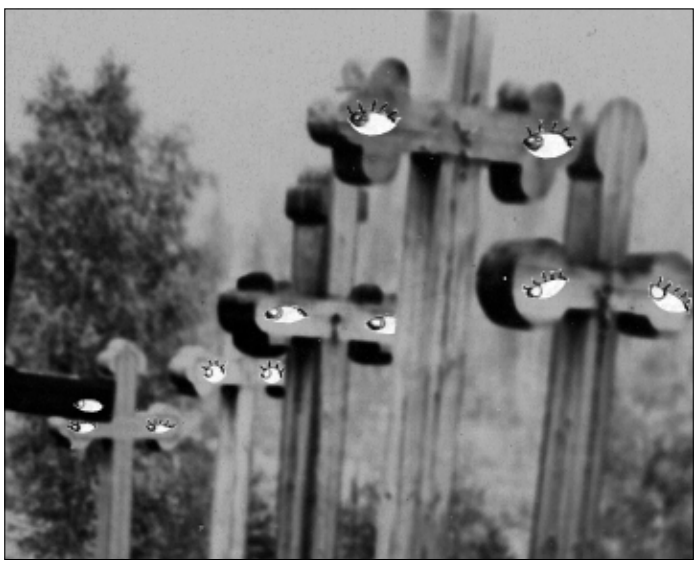

Grandpa and Grandma, dir. Giedrè Beinoriutè, 2007

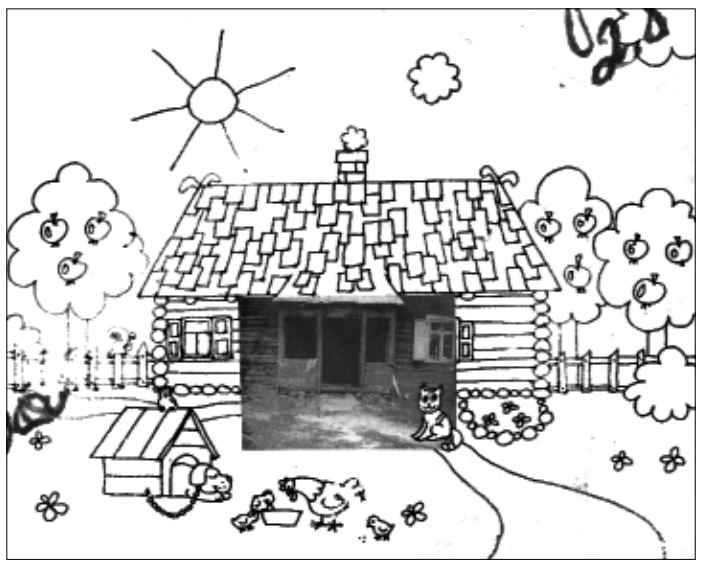

Grandpa and Grandma, dir. Giedrè Beinoriutè, 2007 
Antanas Kraujelisis, related by Algimantas Maceina in the film The Last (Paskutinis, 2010). Vytautas V. Landsbergis, in turn, in the cycle of documentaries The Ballad of Daumantas (Balade apie Daumanta, 1995), Wife of Freedom Fighter (Partizano žmona, 2011) and Tricolour (Trispalve,2013), compiles a history of the tragic fate of the Soviet opposition movement in Lithuania. From recollections, photographs, letters, newsreels, as well as folk songs, a romantic portrait of a post-war hero arises, a partisan fighting for the freedom of Lithuania. The strength of these films lies in the portrayals of people, ones that are artistic and reflect every emotion in a testimony of the tragedy that these people experienced and which left scars deep in them.

The tragic and polemical events in the annals of Lithuanian history also relate to films documenting the tragedy of the Jewish people. The motif of Jewish culture and the Holocaust in Lithuanian documentaries in fact was previously not present. In Soviet times it disappeared from the landscape, as well as from the screen. This most politically sensitive subject has returned to Lithuanian documentaries only in the past decade or so thanks to the films of Saulius Beržinis, a director from the middle generation, philologist and graduate of WGIK (Gerasimov Institute of cinematography). On the motivation and undertaking of the theme of the Holocaust, the director has this to say:

[...] I felt that the world expects truth from us all as to what happened in Lithuania during the Holocaust. If it is at all possible to still do something for those who came to love Lithuania, who saw it as their own, it is to remember their tragedy. The documentary with its particular powers of holding time back is able therefore to overcome the destructive force of time and therefore shape social awareness.[5]

The films of Beržinis are part of the process of bringing memories back, telling a story of the world that has irrevocably passed. They represent a sad journey through ruined apartment houses, overgrown cemeteries and desolate synagogues. These are also films that tell a story of Lithuanian villages that once were Jewish and now are remembered by their former inhabitants: In Memory of Lithuanian Synagogues (Lietuvos sinagogoms atminti, 2002), Care (Rüpestis, 2004), as well as the documentary portraits revealing the tragic fate of Lithuanian Jews during the Shoa: When some of Jonishkis was wrapped in Yiddish sounds (Kai apie Joniškị skambejjo jidiš..., 2006) - a documentary showing the crime of the mass extermination of Jews by inhabitants of a Lithuanian hamlet; End of the Road (Kelio pabaiga, 200o) - a film shot together with Dovid Katz, a record of memories from the last Lithuanians, presently in Belarus; as well as Unwritten Judel Diary (Neparašytas Judelio dienoraštis, 2005) - the story of the Kaunas Jew Judelis Beilis, who by some miracle managed to survive the Kaunas Ghetto. The documentary shows how

[5] The author's interview with Saulius Beržinis, 29.01.2014 (based on manuscript). 
the protagonist returns many years later to his native land, where he comes face-to-face with tragedy and now shares his recollections.

The documentaries of Beržinis are realised using video and the technique of talking heads where commentary is preferable, as is the participation of the film maker in the interview. It is here that recollections dominate, as do photographs, archival documents from the Jewish Museum in Vilnius, and fragments of pre-war newsreels - that make familiar once again the picture of a disappearing Jewish culture and its tragedy. These documentaries do not exhaust the complexity of the Jewish subject in Lithuanian culture and are, importantly, a drop in the ocean of Barthes' still largely 'absent discourse'.

Another interesting turning point in the documentaries at the turn of this century is the so-called woman's documentary. An attempt to help the audience see the intimate world of women is therefore taken up by the films Mild Witchcraft (Lengvas raganavimas, 2005) and the earlier Women's Secret (Moteru paslaptys, 2004) by Inesa Kurklietyte. These documentaries tell the story of giving birth in water. A portrayal is given of the midwife Jurga Švedienè, who helped over 400 children to come into this world. In the documentaries she appears as a magical Shaman to the women, someone in whom they trust their body and soul. These films are a lyrical mosaic of slowly changing images, where the soundtrack becomes the only commentary. Here naturalistic shots of birth, pain and suffering are not present; instead here what dominates are images of the women's bodies immersed in water and those preparing for the most important event in their life. Giving birth in the film by Kurklietyte is portrayed as a magical ritual, one that takes place among candles, side by side with nature in the forest, to the sounds of a Shaman's drums. The scenes of women giving birth are accompanied by the leisurely rhythm of the filming, are intensively lit and are set to mystical music. All of these techniques create a supernatural picture, one that is somewhat mystifying.

The motif of women is also taken up by the films of Janina Lapinskaite in Cast and Crew (Šokanti ant stogu, 2008) and The Widows' Coast (Našliu pakrantè, 2006). The director, a lecturer for many years at the Lithuanian film institute where she is head, in her films attempts to reach the essence of being a woman through various tragic circumstances of life. The films are portraits of women that have been abandoned and are unhappy. The documentary The Widows' Coast portrays a lonely widow living by the seaside in a small town, while Cast and Crew deals with a woman and her memories of being raped, humiliated and beaten in childhood, who now works as a prostitute. Lapinskaite builds a portrait of women with the aid of sets of softly edited scenes and carefully thought out construction - in addition to departing from the well mastered genre of 'talking heads' in television documentaries. In these films there are no close-ups; instead, we only hear a voice off camera against a background of changing images and the space where these protagonists live, the delicate tone of the sea, sad autumn streets (The 
Widows' Coast), derelict buildings, grey streets of the town (Cast and Crew). The recollections of the women are accompanied by a deformation of space with the aid of a wide angle lens, frequent high-angle shots and experiments with sound. These documentaries are characterised by an unusual precision in their choice of formal means and thanks to this the editing, camerawork and constructions of time and space take on a creative force,[6] and cease to be simply a record of the concrete but evolve in the direction of the general and the metaphorical, thereby attempting to reach to the very core of women's feelings.

It can be said therefore that the woman's perspective in Lithuanian documentary is a sign of a new opening in Lithuanian cinematography, one that therefore provides an opportunity to portray a subject that has been unjustifiably forgotten, one that has ceased to function in the common awareness of society. The portrayals are added to by the fact that they not only show the stories of women, but also ones about important social events that are recounted from a woman's perspective.

Another group of documentaries represented with particular eagerness by television and also often of a highly educational value, are biographic documentaries on known figures such as writers, scholars and artists. Among the numerous biographical films here, it is worth noting the documentary on the pioneer of the animated puppet film Władysław Starewicz in the film The Bug Trainer (Vabzdžiu dresuotojas, 2008), the biographies of Linas Augutis, Donatas Ulvydas, Marek Skrobecki, as well as a two-part documentary on the Polish Nobel Prize winner The Age of Czeslaw Milosz (Česlovo Milošo amžius, 2012) directed by Juozas Javaitis. The latter film was shot in Lithuania, Poland, France, Italy and the USA. The archival material here is interwoven with the stories of people who knew Miłosz - among others, his personal secretary Agnieszka Kosińska, the journalist Marek Danner, translators and poets Robert Hass, Natalia Gorbaniewska, and Tomas Venclova, as well as the son of the poet, Antoni.

There have also been several notably worthy documentaries on film makers themselves such as the two-part document by Almantasa Grikevičiusa on her friend Vytautas Žalakevičius Notes in the Margins of a Life Style (Pastabos gyvenimo büdo paraštese, 2002), as well as the documentary by Agne Marcinkevičiutè We Have Talked on Time (Laiku suspejome pasikalbeti, 2006) on director Raimondas Vabalas. These films attempt to penetrate the world of inspiration where directors interpret their own films, and relate the circumstances of how they came about. These are the only testimonies where it is possible to hear the voices of the 'classics' of Lithuanian feature film who are no longer alive.

The historical and biographical documentaries, canvassing important events in the history of Lithuania, as well as films that portray the world of women - are ones that introduce a particular variety and increase the field of interest in the subject matter pursued by Lithua-

[6] See M. Przylipiak, Poetyka kina dokumentalnego [The Poetics of Documentary Film], Wydawnictwo
Uniwersytetu Gdańskiego, Gdańsk-Słupsk 2004, pp. 210-230. 
nian documentary films. The majority of the films mentioned above are based on former historical documents and are iconographic, with commentary as the main unifying structure of the film's motif.

If one were to attempt to place Lithuanian documentary films in this century according to the typology existing in fact from the beginning of cinematography that divides filmmakers into those believing in reality (the Lumière School) and those believing in the image (the Méliès School), the latter is decidedly closer to Lithuanian documentalists in viewing the world. The Lithuanian documentary realised in auteur film production companies as yet does not have the courage to play the role of direct commentator on political and social events. Nor does Lithuanian documentary film adapt a journalistic style with a marked tone of observation in its style as a document. The search for a formal, painstakingly constructed visual aspect, lyricism of narration and authorial point of view are characteristic for every type of documentary film. Subjectivity and the creative form is present also in historical documentaries such as Grandpa and Grandma, How We Played the Revolution), biographical films (The Bug Trainer, The Age of Czeslaw Milosz), documentaries dealing with the woman's point of view (Women's Secret, The Widows' Coast, Cast and Crew), as well as the uniquely anthropological perspective of Mantas Kvedaravičius. The history of Lithuanian documentary film is according to the scholar Bill Nichols one of a style that is still poetical, which 'emphasizes visual associations, tonal or rhythmic qualities, descriptive passages, and formal organization".[7]

At the turn of the century the narrational line of the poetical form of the documentary, however, began changing. It can be said therefore that the documentary film by the younger generation has breathed, as it were, new content into an old form and therefore provoked a thorough reflection on the condition of man in the contemporary world, as well as the passing from national priorities characteristic for film in the 196os. Young documentary filmmakers, taking full advantage of their technical skills, artistic sensitivities and perspicacity in choosing the poetic form, the creative modus operandi for their films, attempt to discover the truth about people and communities that make up the subject matter of their films. In this way they focus on man and his fate as an individual. Here, the camera is close to the person, observing him patiently and carefully. It is not, however, a form of observation that seeks to admonish or one that brands in any way, but rather one of goodwill and understanding.

Man, observed on-screen by the young generation of directors, is always concrete, at ease in the presence of the camera, engaged in everything that is part of the everyday, known and clear for him. The young directors also search for more attractive, moving subjects and [7] B. Nichols, Introduction to Documentary, Indiana University Press, Bloomington 2001, p. 33. 
have sought to broaden the geographic space, as it were, of the document. Their films therefore are not restricted to the provincial but also reach for the Caucuses, Belarus and Georgia. These are not only the portraits of aged Lithuanians illustrated through folk songs off camera, but also the portrayal of people in the face of political oppression (Barzakh), in the face of loneliness and deprivation (The Field of Magic, Igrushki, Sasha, Ramin) and ones of brimming family happiness ( $\mathrm{Fa}$ ther). This latter film does/These films do not battle the imperfections of our age, does not transform what the documentary has to say into a product - into an effective and resonant 'what' and a slogan 'how', to use the words of Kazimierz Karabasz.[8] The works of Lithuanian documentary filmmakers distinguish themselves by an emphasis on an unhurried camera, authorial contemplation through the use of images, bringing an awareness of the auteur style, which does not take into account passing vogues, profit or the limelight of 'cheap' popularity. In return, the Lithuanian documentary is always true to itself and attempts to present its own vision of the world to its audience.

The fundamental mission of documentary film, one tied to the memory of man and the individual as the main governing metaphor, remains, in the view of this author, still valid in Lithuanian cinema.

[8] K. Karabasz, "Film dokumentalny dzisiaj" [Documentary Film Today], Kwartalnik Filmowy 1998, no. 23, p. 121. 